\title{
Endothelin Enhances the Contractile Responsiveness of Adult Rat Ventricular Myocytes to Calcium by a Pertussis Toxin-sensitive Pathway
}

\author{
Ralph A. Kelly, Hoda Eid, Bernard K. Krämer, Mary O'Neill, Bruce T. Liang, Martin Reers, and Thomas W. Smith \\ Department of Medicine, Cardiovascular Division, Brigham and Women's Hospital and Harvard Medical School, \\ Boston, Massachusetts 02115
}

\begin{abstract}
It has long been assumed that the primary influences regulating cardiac contractility are the extent of mechanical loading of muscle fibers and the activity of the autonomic nervous system. However, the vasoactive peptide endothelin, initially found in vascular endothelium, is among the most potent positively inotropic agents yet described in mammalian myocardium. In isolated adult rat ventricular cells, endothelin's action was slow in onset but very long lasting with an $\mathrm{EC}_{50}$ of $50 \mathrm{pM}$ that approximates the reported $K_{D}$ of the peptide for its receptor in rat heart. When the calcium activity of the buffer superfusing isolated single fura-2-loaded myocytes paced at $1.5 \mathrm{~Hz}$ was varied from 0.1 to $0.9 \mathrm{mM}\left[\mathrm{Ca}^{2+}\right]_{0}, 100 \mathrm{pM}$ endothelin increased contractile amplitude with no significant change in diastolic or systolic $\left[\mathrm{Ca}^{2+}\right]_{i}$, thus appearing to sensitize the myofilaments to intracellular calcium. Pertussis toxin, or prior exposure to a $\beta$-adrenergic agonist, reduced or abolished the increase in myocyte contractility induced by endothelin. This novel and potent pharmacologic action of endothelin points to the potential importance of local, paracrine factors, perhaps derived from microvascular endothelium or endocardium, in the control of the contractile function of the heart. (J. Clin. Invest. 1990. 86:1164-1171.) Key words: inotropy $\bullet \beta$-adrenergic • endothelium • fura-2 - myocardium
\end{abstract}

\section{Introduction}

Endothelial cells have been identified as the source of a number of biologically active factors that act in a paracrine fashion to influence the behavior of both blood-borne elements and subjacent vascular tissue (1-3). One such factor is the potent vasoconstrictor endothelin, originally identified by Masaki and colleagues in conditioned media from primary cultures of porcine aortic endothelial cells (4). Their initial reports describing endothelin's positive inotropic effect (i.e., increasing contractility) in guinea pig atria, and its action on the secretion of atrial natriuretic peptide in primary cultures of neonatal rat atrial myocytes $(5-7)$ have been confirmed by several laborato-

This work was presented in abstract form at the 62 nd Annual Scientific Meetings of the American Heart Association, November 1989, New Orleans, LA.

Address correspondence to Dr. R. A. Kelly, Cardiovascular Division, Brigham and Women's Hospital, 75 Francis Street, Boston, MA 02115.

Received for publication 14 December 1989 and in revised form 18 May 1990.

J. Clin. Invest.

(c) The American Society for Clinical Investigation, Inc. $0021-9738 / 90 / 10 / 1164 / 08 \quad \$ 2.00$

Volume 86, October 1990, 1164-1171 ries (8-15). Subsequently, high-affinity receptors for endothelin have been identified by several groups in mammalian atria and ventricles (16-21). We report here that endothelin is the most potent positively inotropic agent we have tested in isolated adult rat ventricular myocytes. This inotropic effect was abolished by pretreatment with pertussis toxin, thus implicating a guanine nucleotide regulatory $(G)$ protein or proteins in the sequence of steps leading to the inotropic response.

Masaki and colleagues have now demonstrated that at least three isoforms of endothelin are coded in the mammalian genome, all very similar structurally, but varying in the hydrophilicity of their $\mathrm{NH}_{2}$-terminal sequences (22). These peptides have qualitatively similar pharmacodynamic effects, although the pharmacokinetics of their action on varying tissues could differ. For the purpose of this report, "endothelin" refers to the originally described porcine/human endothelin, now termed "endothelin-1."

\section{Methods}

Calcium-tolerant isolated rat ventricular myocytes were prepared using a variation of the methods described by Haworth et al. (23) and Cheung et al. (24). Briefly, hearts were perfused with a Krebs-Henseleit bicarbonate buffer containing nominally $0 \mathrm{Ca}^{2+}$, collagenase, and hyaluronidase (Worthington Biomedical, Malvern, PA). Ventricles were minced and incubated in the same buffer containing trypsin and $1 \mathrm{mM}$ $\mathrm{CaCl}_{2}$, and cells were released by trituration and sedimentation in $2 \%$ BSA. The yield of rod-shaped cells $\left(1.5-2.0 \times 10^{6}\right.$ cells/heart $)$ in the top layer of the cell suspension with clear cross-striations that excluded trypan blue was routinely $>95 \%$. The myocytes were then allowed to attach to $12-\mathrm{mm}$ glass coverslips that had been coated with collagen (Vitrogen 100; Collagen Corp., Palo Alto, CA) for contractility measurements. For measurement of intracellular $\mathrm{Ca}^{2+}$, cells were first loaded with fura-2/AM by incubating $2 \mathrm{ml}$ of cell suspension $(\sim 5$ $\times 10^{4}$ cells $/ \mathrm{ml}$ ) with $0.1 \mathrm{ml}$ of a $4.8 \mu \mathrm{M}$ fura- $2 / \mathrm{AM}$ stock solution $(0.5$ $\mathrm{ml}$ of $1 \mathrm{mM}$ fura-2/AM in dry DMSO with $0.1 \mathrm{ml} 25 \%$ (wt/wt) Pluronic F127 in DMSO (Molecular Probes Inc., Eugene, OR) and $4.4 \mathrm{ml}$ FCS). The cells were then washed in Hepes-buffered medium (below), and allowed to attach to glass coverslips coated with liquid collagen (Vitrogen, Collagen Corp.) and stored in the dark until use. The fura-2 stock solution was sonicated and stored at $-70^{\circ} \mathrm{C}$ in aliquots for future use. Endothelin (synthetic porcine/human endothelin-1) was purchased from Penisula Laboratories Inc. (Belmont, CA). The lyophilized peptide was reconstituted in $1.0 \mathrm{mM}$ acetic acid to a final concentration of $40 \mu \mathrm{M}$, aliquoted, and kept at $4^{\circ} \mathrm{C}$ for no longer than 2 wk. To minimize nonspecific adsorption of the peptide to surfaces, all dilute solutions of endothelin were maintained in $0.05 \%$ BSA (Fraction V; Sigma Chemical Co., St. Louis, MO).

Contractility and intracellular $\mathrm{Ca}^{2+}$ measurements. Cardiac myocytes were superfused at $1 \mathrm{ml} / \mathrm{min}$ with medium containing $140 \mathrm{mM}$ $\mathrm{NaCl}, 4.0 \mathrm{mM} \mathrm{KCl}, 0.5 \mathrm{mM} \mathrm{MgCl}, 0.9 \mathrm{mM} \mathrm{CaCl}_{2}, 5.6 \mathrm{mM}$ glucose, $2 \% \mathrm{FCS}, 0.05 \% \mathrm{BSA}$, and $5 \mathrm{mM}$ Hepes at $37^{\circ} \mathrm{C}, \mathrm{pH} 7.4$. The cells were electrically stimulated with silver electrodes at $1.5 \mathrm{~Hz}$ with $3-\mathrm{ms}$ pulses. Light-dark contrast at the cell end provided a marker for measurement of amplitude and velocity of cell motion. In this cell preparation, the 
velocity of cell shortening varied linearly with contractile amplitude, and, therefore for convenience, only the latter data are presented here. Cell shortening and relaxation were monitored using a video motion detector that provided new position data every $16 \mathrm{~ms}$. In cells not exposed to agonist, the absolute magnitude of shortening varied from $1-5 \mu \mathrm{m}$ (mean $3.79 \pm 1.40 \mu \mathrm{m} ; \pm \mathrm{SD}$ ), increasing to $>10$-fold in the presence of high concentrations of external calcium or isoproterenol. For the simultaneous measurement of contractility and $\left[\mathrm{Ca}^{2+}\right]_{i}$, isolated adult rat ventricular myocytes were loaded with the calcium-selective fluorescent dye fura-2 (1-[2-(5-carboxyoxazol-2-yl)-6-aminobenzofuran-5-oxyl]-2-(2'-amino-5'-methylphenoxy)ethane- $N, N, N^{\prime}, N^{\prime}$ tetraacetic acid) (Molecular Probes Inc.). Coverslips containing attached fura-2-loaded myocytes were transferred to a circular superfusion chamber $12-\mathrm{mm}$-diam, $300 \mu \mathrm{l}$ in volume, mounted on the stage of an inverted epifluorescence microscope (Nikon, Diaphot). The coverslips were superfused by a peristaltic pump at a flow rate of $1 \mathrm{ml} / \mathrm{min}$. Both the chamber and superfusate were kept at $37^{\circ} \mathrm{C}$ by a circulating water bath. The microscope was connected to a dual excitation fluorometer (Spex Industries, Inc., Edison, NJ). The excitation wavelengths were $340 / 380 \pm 1.8 \mathrm{~nm}$. The emission spectrum of fura-2 at each excitation wavelength was monitored at $500 \pm 5 \mathrm{~nm}$, with a time resolution for acquisition of ratioed data of $3 \mathrm{~ms}$. To minimize photobleaching of the dye, a $50 \%$ neutral density filter was inserted in the excitation beam path. The cells were also illuminated with light at a wavelength above $600 \mathrm{~nm}$ in the phase contrast mode. An additional postspecimen dichroic mirror deflected light at wavelengths below 450 $\mathrm{nm}$ to a video camera, thereby minimally affecting the emission light from fura-2. Ventricular myocytes were loaded with $2 \mu \mathrm{M}$ fura-2/AM (the acetoxymethylester of fura-2) for $30 \mathrm{~min}$ at room temperature in superfusion buffer. This step reduced the amplitude of contraction of individual cells by no more than $10 \%$ at $0.9 \mathrm{mM} \mathrm{Ca}^{2+}$.

Because the positive inotropic response to endothelin was slow in onset, preliminary experiments were performed to characterize the contractile response of fura-2-loaded myocytes monitored on the stage of an epifluorescence microscope at $37^{\circ} \mathrm{C}$ for up to $90 \mathrm{~min}$. In contrast to our experience monitoring the behavior of isolated ventricular myocytes in a standard phase-contrast microscope, myocyte contractility was markedly reduced in fura-2-loaded cells constantly exposed to UV light at 340 and $380 \mathrm{~nm}$. Whether this deleterious effect was directly related to cellular toxicity due to UV light, or to a toxic metabolite of fura-2 as a consequence of photobleaching, is unclear. Therefore, in protocols involving fura-2-loaded myocytes, the contractile response of individual cells illuminated by a standard microscope light source was monitored until a plateau was reached following a change in the superfusion medium. A "snapshot" of the calcium transients lasting $<30 \mathrm{~s}$ was then obtained by opening an electronic shutter, thus minimizing the total cellular exposure to UV light to $<7$ min during an entire protocol. This toxic effect was accelerated by exposure to high $(5.4 \mu \mathrm{M})\left[\mathrm{Ca}^{2+}\right]_{0}$. Therefore, contractility signals are expressed as a percentage of the baseline contractile amplitude rather than as a percentage of the maximum response possible for each cell.

After completion of an experimental protocol, in situ calibration of the fura-2 fluorescence signal was accomplished by either of two methods: superfusion of cells with ionophores and $\mathrm{Ca}^{2+}$ calibration buffers alone, or superfusion of myocytes with ionophores and $\mathrm{La}^{3+}$ to maintain cell shape during calibration (see below). In the first method, myocytes were initially superfused with $4 \mu \mathrm{M}$ ionomycin in superfusion buffer with $2 \mathrm{mM}$ EGTA and no added calcium at $\mathrm{pH} 7.4$, followed by this same buffer containing $2 \mu \mathrm{M} \mathrm{CCCP}, \mathrm{pH} 7.15$. After the fura-2 emission spectra had stabilized at a minimum value, the cells were superfused with buffer containing $0.9 \mathrm{mM} \mathrm{Ca}^{2+}, 4 \mu \mathrm{M}$ ionomycin, $2 \mu \mathrm{M}$ CCCP at pH 7.15. Finally, the autofluorescence of the cell and the contribution of partially hydrolyzed, $\mathrm{Ca}^{2+}$-insensitive fura-2 could then be determined by the addition of $1 \mathrm{mM} \mathrm{Mn}^{2+}$ to quench the fura-2 within the cell.

Many cells could not be calibrated in this fashion because of the propensity of isolated myocytes to undergo shape changes during the superfusion of $\mathrm{Ca}^{2+}$ calibration buffers. Consequently, we developed a calibration method that exploits the properties of lanthanum ion to induce myofilament relaxation (25). The substitution of lanthanum for calcium allows determination of ion-saturated fura-2 fluorescence under conditions where both cell shape and energy status are preserved. Using this technique, adult myocytes were individually calibrated in situ by sequential exposure to calibration buffers containing (a) the standard superfusion buffer with $1 \mathrm{mM}$ EGTA and $5 \mathrm{mM}$ pyruvate for $30 \mathrm{~s}$; (b) superfusion buffer with $10 \mu \mathrm{M}$ ionomycin for at least 5 min until a stable signal was achieved; and $(c)$ superfusion with $10 \mu \mathrm{M}$ ionomycin and $1 \mathrm{mM} \mathrm{LaCl}{ }_{2}$ (no EGTA) for 2-3 min until a stable maximum was achieved. $\left[\mathrm{Ca}^{2+}\right]_{\mathrm{i}}$ was then determined as described by Grynkiewicz et al. (26) with a correction for the altered ion binding and spectral properties of fura- 2 with $\mathrm{La}^{3+}$ compared to $\mathrm{Ca}^{2+}$. Fura-2 displays a hypsochromic effect of $6 \mathrm{~nm}$ on binding $\mathrm{La}^{3+}$ with both hyperchromic (at $340 \mathrm{~nm}$ ) and hypochromic (at $380 \mathrm{~nm}$ ) effects, and an affinity for $\mathrm{La}^{3+}$ that is much higher than for $\mathrm{Ca}^{2+}$ or for $\mathrm{Mn}^{2+}$; therefore, correction factors have been derived and validated (25). Although the sampling rate of the spectrofluorometric instrumentation used in collecting the data in this report was sufficiently rapid (a ratioed fura-2 signal every $3 \mathrm{~ms}$ ) to capture systolic and diastolic values for cytosolic $\mathrm{Ca}^{2+}$ reliably, no comment can be made about the rate of decline of intracellular $\mathrm{Ca}^{2+}$ transients in control, isoproterenol or endothelin-treated cells due to the concern that the dissociation rate of $\mathrm{Ca}^{2+}$ from the fura- $2 / \mathrm{Ca}^{2+}$ complex might limit the resolution of the time course of the decline in cytosolic $\left[\mathrm{Ca}^{2+}\right]$.

Exposure of myocytes to pertussis toxin. Freshly isolated rodshaped cells were suspended in Hepes-buffered medium and incubated at $37^{\circ} \mathrm{C}$ with $100 \mathrm{ng} / \mathrm{ml}$ pertussis toxin for $3 \mathrm{~h}$. The in vitro ADP-ribosylation reaction then was performed at $37^{\circ} \mathrm{C}$ for $40 \mathrm{~min}$ as previously described (27). Analysis of protein bands was performed on $11 \%$ acrylamide gels prepared according to Laemmli (28). Dried gels were exposed to Kodak XAR film with enhancing screens for $1-2 \mathrm{~d}$ at $-70^{\circ} \mathrm{C}$. Autoradiographs were scanned on a laser densitometer (LKB Instruments, Inc., Gaithersburg, MD). Fig. 6 depicts an autoradiogram of SDS-PAGE of pertussis toxin-treated and control cell homogenates.

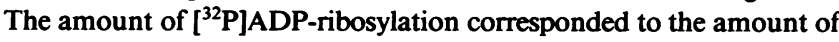
pertussis toxin-sensitive unreacted $G$ protein(s) and was inversely proportional to the amount of G protein ADP-ribosylated from the endogenous NAD in the intact myocyte.

\section{Results and Discussion}

Endothelin and myocyte contractile amplitude. To obviate the potential complication of diffusion limitations and the presence of cells other than myocytes that might bind and metabolize the peptide in intact tissue preparations, we studied the calcium-tolerant isolated adult rat ventricular myocyte, an experimental model that has been characterized in detail in our laboratory. In Fig. 1, the contractile response of isolated ventricular myocytes is plotted as a function of endothelin concentration in the bathing media. Due to a tendency for cells to have a diminished response to higher doses of the peptide after a 7-10-min exposure at a lower concentration (e.g., 0.5-10 pM), the concentration-effect curve was constructed testing individual cells at one endothelin concentration only ( $n$ $=6-10$ cells at each point).

In this preparation, it was apparent that endothelin was the most potent positively inotropic agent we have tested to date, with a characteristic slow onset and long duration of action. Although occasional cells showed a definite response between 10 and $100 \mathrm{fM}$, consistent responses were apparent only above $0.5 \mathrm{pM}$; the $\mathrm{EC}_{50}$ was $50 \mathrm{pM}$. In contrast, similar increases in contractile amplitude (140-190\% of control amplitude) were obtained only at significantly higher doses of other agonists (e.g., $10 \mathrm{nM}$ isoproterenol, $30 \mathrm{nM}$ Bay K 8644, or $100 \mu \mathrm{M}$ 


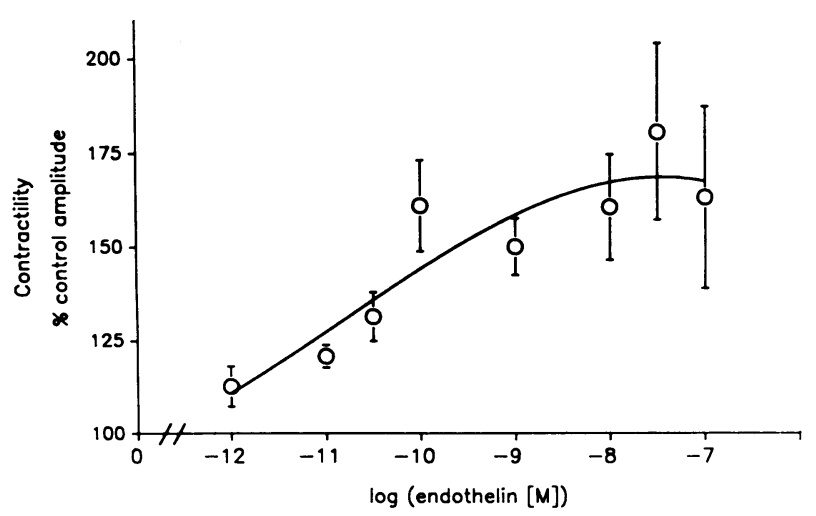

Figure 1. Concentration-effect relationship of endothelin in isolated adult rat ventricular myocytes. Changes in contractile amplitude in single cardiac myocytes were measured using an optical-video system as described in Methods. Due to a tendency for cells to have a diminished response to higher doses of the peptide after a 7-10-min exposure at a lower concentration (e.g., $0.5-10 \mathrm{mM}$ ), the concentration-effect curve was constructed using individual cells at one concentration only ( $n=6-10$ cells at each point).

phenylephrine). Nevertheless, the average maximal response or efficacy of endothelin at $500 \mathrm{pM}$ approximated $60 \%$ of the maximal response to $1 \mu \mathrm{M}$ isoproterenol or high $(5.4 \mathrm{mM})$ $\left[\mathrm{Ca}^{2+}\right]_{0}$ in this model. Interestingly, the contractile response of cells exposed to concentrations of endothelin above $10 \mathrm{nM}$ was not consistent. Approximately one-half of the cells examined had limited inotropic responses (105-150\% of control), while the remainder had an increase in contractile amplitude of $170-250 \%$. The reason for this variability is unclear.

After addition of endothelin to the superfusion medium, the time to onset of an inotropic response was 4-6 min; the mean time to reach the maximum contractile response of a cell over a dose range from $0.5 \mathrm{pM}$ to $100 \mathrm{nM}$ was $7.7 \pm 2.7 \mathrm{~min}$ (mean $\pm \mathrm{SD} ; n=70$ cells). At any endothelin concentration, the time for a fall in inotropic response after removal of the peptide from the superfusion medium was relatively long (usually
$>8 \mathrm{~min}$ ) with little or no change in contractile amplitude observed in $50 \%$ of cells even at $15 \mathrm{~min}$ after washout. The prolonged action of endothelin may be due either to delayed dissociation from sarcolemmal receptors, a prolonged generation of an intracellular signal, or both. At the present time, we have no evidence to support either mechanism.

Intracellular $\left[\mathrm{Ca}^{2+}\right]$ and myocyte contractility. Since most positively inotropic agents typically act by increasing cytosolic calcium $(29,30)$, contractility and cytosolic calcium activity $\left(\left[\mathrm{Ca}^{2+}\right]_{\mathrm{i}}\right)$ were measured concurrently in isolated rat ventricular myocytes using the calcium-selective fluorescent dye fura-2. The relationship between changes in $\left[\mathrm{Ca}^{2+}\right]_{\mathrm{i}}$ and contractile amplitude was examined either by exposing myocytes to graded concentrations of $\left[\mathrm{Ca}^{2+}\right]_{0}$ in the presence or absence of endothelin or by comparing the inotropic response of myocytes to endothelin with that of the $\beta$-adrenergic agonist, isoproterenol.

To examine the relationship between $\left[\mathrm{Ca}^{2+}\right]_{\mathrm{i}}$ and contractility over a range of external $\left[\mathrm{Ca}^{2+}\right]_{0}$ in the presence and absence of endothelin, each ventricular myocyte was subjected to stepwise reductions in $\left[\mathrm{Ca}^{2+}\right]_{0}$ from $0.9 \mathrm{mM}$ to $0.1 \mathrm{mM}$, followed by a stepwise return to $0.9 \mathrm{mM}$ calcium in the presence of 0 or $100 \mathrm{pM}$ endothelin. This protocol has the virtue of allowing paired comparisons of $\left[\mathrm{Ca}^{2+}\right]_{\mathrm{i}}$ and contractile amplitude in the same cell in the presence and absence of endothelin, over a range of external $\left[\mathrm{Ca}^{2+}\right]_{0}$. However, the use of a descending-ascending $\left[\mathrm{Ca}^{2+}\right]_{0}$ protocol such as this presumes the absence of any substantial degree of hysteresis in either $\left[\mathrm{Ca}^{2+}\right]_{\mathrm{i}}$ or contractility over the range of $\left[\mathrm{Ca}^{2+}\right]_{0}$ studied. In ventricular myocytes not loaded with fura- 2 and stepped through a similar protocol, there was no hysteresis in the contractile response to calcium in the absence of endothelin $(n=7$ cells). Similarly, in fura-2-loaded myocytes not exposed to endothelin, there was no hysteresis in contractile amplitude between the $\left[\mathrm{Ca}^{2+}\right]_{\mathrm{o}}$ step down and step up stages of the protocol nor was there a significant change in the systolic $\left[\mathrm{Ca}^{2+}\right]_{\mathrm{i}}$ at any given $\left[\mathrm{Ca}^{2+}\right]_{0}$ in control cells, as indicated by the absence of any significant degree of variance for systolic $\left[\mathrm{Ca}^{2+}\right]_{\mathrm{i}}$ at each point in the control cells (Fig. $2 \mathrm{~B}$, open diamonds).
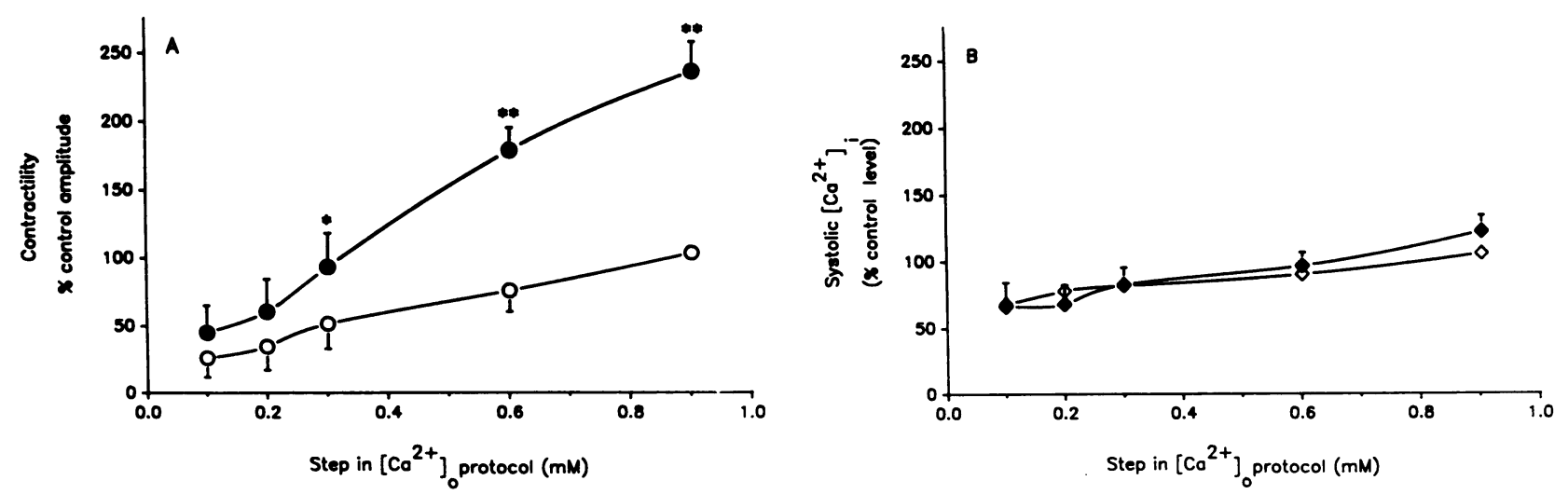

Figure 2. Endothelin enhances the contractile response to $\left[\mathrm{Ca}^{2+}\right]_{0}$. The relationship between changes in external calcium activity $\left(\left[\mathrm{Ca}^{2+}\right]_{0}\right)$ and myocyte contractile amplitude was investigated in rat ventricular myocytes, loaded with the calcium-selective fluorescent dye fura-2. Cells were exposed initially to $0.9 \mathrm{mM}\left[\mathrm{Ca}^{2+}\right]_{0}$ followed by stepwise reductions in $\left[\mathrm{Ca}^{2+}\right]_{0}$ to $0.1 \mathrm{mM}$. Each cell was then exposed to medium alone or to $100 \mathrm{pM}$ endothelin at $0.1 \mathrm{mM}\left[\mathrm{Ca}^{2+}\right]_{\mathrm{o}}$ and subsequently stepped back up to $0.9 \mathrm{mM}\left[\mathrm{Ca}^{2+}\right]_{\mathrm{o}} . A$ and $B$ illustrate, respectively, the contractile amplitude and peak systolic $\left[\mathrm{Ca}^{2+}\right]_{\mathrm{i}}$ as a percentage of their initial values at $0.9 \mathrm{mM}\left[\mathrm{Ca}^{2+}\right]_{\mathrm{o}}$ at the beginning of the protocol for three control cells (open symbols) and three cells exposed to $100 \mathrm{pM}$ endothelin during the step up phase only (solid symbols). A $t$ test for paired observations was used with a modified Bonferroni correction for multiple comparisons $\left({ }^{*}, P<0.05 ;{ }^{* *}, P<0.01\right)$. 
In contrast, in those cells exposed to $100 \mathrm{pM}$ endothelin during the step up from 0.1 to $0.9 \mathrm{mM}\left[\mathrm{Ca}^{2+}\right]_{\mathrm{o}}$, there was a marked increase in contractile amplitude even at $0.1 \mathrm{mM}$ $\left[\mathrm{Ca}^{2+}\right]_{\mathrm{o}}$ (Fig. $2 \mathrm{~A}$ ). At $0.1 \mathrm{mM}\left[\mathrm{Ca}^{2+}\right]_{\mathrm{o}}$ in the absence of the peptide, 2 of 3 cells had stopped contracting despite continuing stimulation pulses, but began beating $\sim 5 \mathrm{~min}$ after being switched to endothelin-containing medium. Importantly, despite a marked increase in contractile amplitude that averaged $234 \%(n=3)$ of baseline at $0.9 \mathrm{mM} \mathrm{Ca}^{2+}($ Fig. $2 A)$, there was no significant increase in the systolic $\mathrm{Ca}^{2+}$ (Fig. $2 B$ ) or in the diastolic $\left[\mathrm{Ca}^{2+}\right]_{\mathrm{i}}$ or time averaged $\left[\mathrm{Ca}^{2+}\right]_{\mathrm{i}}$ (data not shown).

The calcium data in Figs. $2 B$ and $3 A$ are normalized to the systolic $\mathrm{Ca}^{2+}$ values at $0.9 \mathrm{mM}\left[\mathrm{Ca}^{2+}\right]_{0}$ at the beginning of the protocol. Using $\mathrm{La}^{3+}$, both to prevent changes in cell shape and to calibrate in situ the fura- 2 signal in myocytes (see Methods and reference 25$)$, the systolic $\left[\mathrm{Ca}^{2+}\right]_{\mathrm{i}}$ at $0.9 \mathrm{mM}\left[\mathrm{Ca}^{2+}\right]_{0}$ ranged from 820 to $1050 \mathrm{nM}$ and the diastolic $\left[\mathrm{Ca}^{2+}\right]_{\mathrm{i}}$ ranged from 48 to $110 \mathrm{nM}$ in cells paced at $1.5 \mathrm{~Hz}$.

When the relationship between cytosolic calcium and contractile amplitude induced by step changes in $\left[\mathrm{Ca}^{2+}\right]_{0}$ is examined, as shown in Fig. $3 \mathrm{~A}$, endothelin appears to increase myofilament responsiveness to cytosolic calcium. To determine if this pharmacologic response to endothelin was qualitatively different from that observed with another positively inotropic agent, rat ventricular myocytes were exposed to either $100 \mathrm{pM}$ endothelin or low concentrations of the $\beta$-adrenergic agonist isoproterenol that resulted in similar increases in contractile amplitude. As illustrated in Fig. $3 B$, although an increase in systolic $\left[\mathrm{Ca}^{2+}\right]_{\mathrm{i}}$ was observed in at least one cell in association with a $250 \%$ increase in contractility with endothelin, when compared to the response to isoproterenol, endothelin exposure produced a greater increment in contractile amplitude for any given change in $\left[\mathrm{Ca}^{2+}\right]_{\mathrm{i}}$. The concentration of isoproterenol used in this study $(5-50 \mathrm{nM})$ was below that reported to induce a decrease in myofilament sensitivity to cytosolic $\mathrm{Ca}^{2+}(32)$, but we cannot exclude such an effect on isolated rat ventricular myocytes in our experiments. Interestingly, an increase in peak systolic calcium and diastolic calcium was variably seen in some isolated myocytes exposed to relatively high concentrations of endothelin (> $5 \mathrm{nM}$; data not shown).

In each of the experiments described above, after determination of the baseline $\left[\mathrm{Ca}^{2+}\right]_{\mathrm{i}}$ and contractile amplitude, we routinely did not measure $\left[\mathrm{Ca}^{2+}\right]_{\mathrm{i}}$ until there was an increase in contractile amplitude with endothelin to prevent nonspecific toxicity due to UV excitation light. To exclude the possibility that there was a transient rise in $\left[\mathrm{Ca}^{2+}\right]_{i}$ in the first several minutes following administration of endothelin, $\left[\mathrm{Ca}^{2+}\right]_{\mathrm{i}}$ was observed in three cells continuously for $60 \mathrm{~s}$ at 1 -min intervals for $10 \mathrm{~min}$ after addition of $100 \mathrm{pM}$ endothelin. The raw data for $\left[\mathrm{Ca}^{2+}\right]_{i}$ transients (the $340 / 380$ ratio of the fura- 2 excitation signal) and contractility from one representative cell are shown in Fig. 4. In no cell was a rise in diastolic, systolic, or the time-averaged integral of $\left[\mathrm{Ca}^{2+}\right]_{\mathrm{i}}$ transient detected, although in each cell there was the expected rise in contractile amplitude.

These observations are made on unloaded cells; that is, the cells undergo shortening against an internal load that is presumed to be constant (isotonic), as opposed to contraction against an external load which more closely represents conditions in vivo. Nevertheless, some recent observations support the usefulness of the isolated myocyte model in the study of cardiac contractility. Lee and Allen, in isolated ferret papillary muscles, have shown qualitatively similar results of several interventions on contractile performance measured either as isotonic muscle shortening or isometric tension development (31). In addition, Kent et al. have recently shown that the rate and extent of shortening of unfettered isolated feline myocytes is analogous to the force-velocity relationship of isolated linear cardiac muscle (33).

The evidence presented here that endothelin enhances myocyte contractility in the absence of substantial changes in time averaged $\left[\mathrm{Ca}^{2+}\right]_{i}$ or in the cystolic $\left[\mathrm{Ca}^{2+}\right]_{\mathrm{i}}$ transient is of interest in relation to recent observations on the mechanism of action of $\alpha$-adrenergic agonists $(33,34)$. In intact aequorinloaded rabbit papillary muscles (34) and in the hyperpermeable rat ventricular strip preparations $(35,36), \alpha$-adrenergic agonists have been reported to increase contractility by two
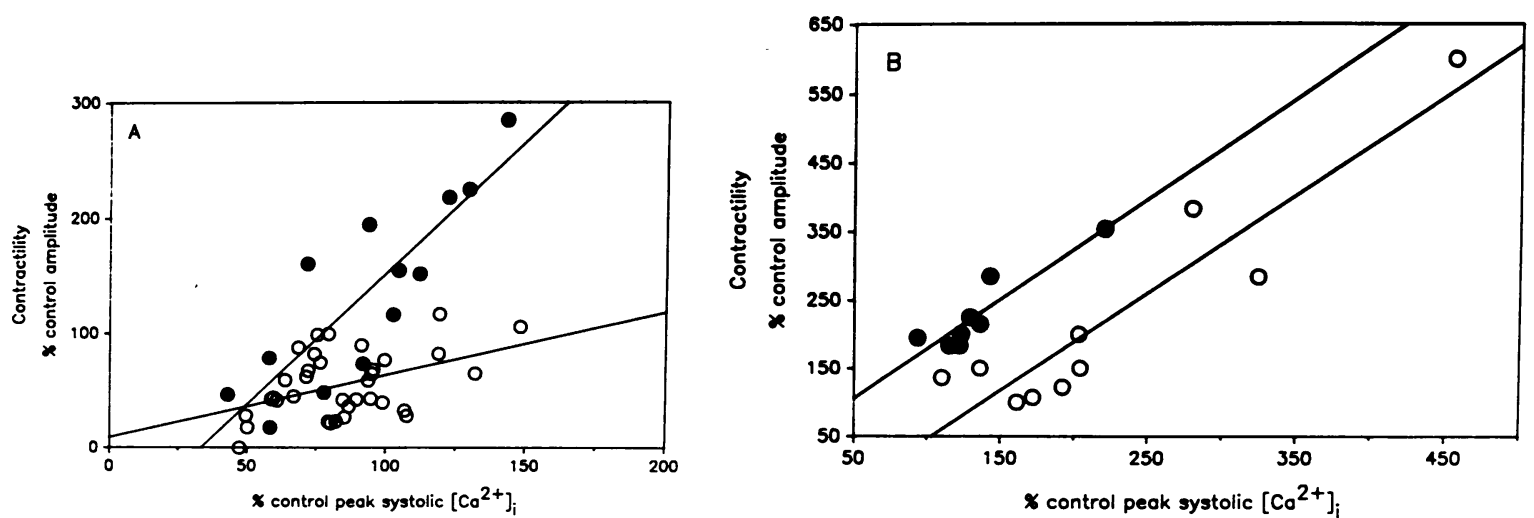

Figure 3. Endothelin enhances the contractile response to $\left[\mathrm{Ca}^{2+}\right]_{\mathrm{i}} \cdot(A)$ The values for contractile amplitude and peak systolic $\left[\mathrm{Ca}^{2+}\right]_{\mathrm{i}}$ in 6 cells at the beginning of the protocol described in Fig. 2 were assigned a value of $100 \%$, and the relative contractility and systolic $\left[\mathrm{Ca}^{2+}\right]_{\mathrm{i}}$ responses for each cell are shown for the subsequent descending and ascending steps of the protocol for control cells (open circles), and for cells exposed to $100 \mathrm{pM}$ endothelin during the ascending limb only (solid symbols). (B) Fura-2-loaded ventricular myocytes were exposed to either $100 \mathrm{pM}$ endothelin or a concentration of sufficient isoproterenol $(5-50 \mathrm{nM})$ to yield a roughly equivalent increase in contractile amplitude. The data are expressed as a percentage of contractile amplitude and systolic calcium above predrug control values at $0.9 \mathrm{mM}\left[\mathrm{Ca}^{2+}\right]_{0}$ for eight endothelin-exposed cells (solid symbols) or 10 isoproterenol-exposed cells (open symbols). 


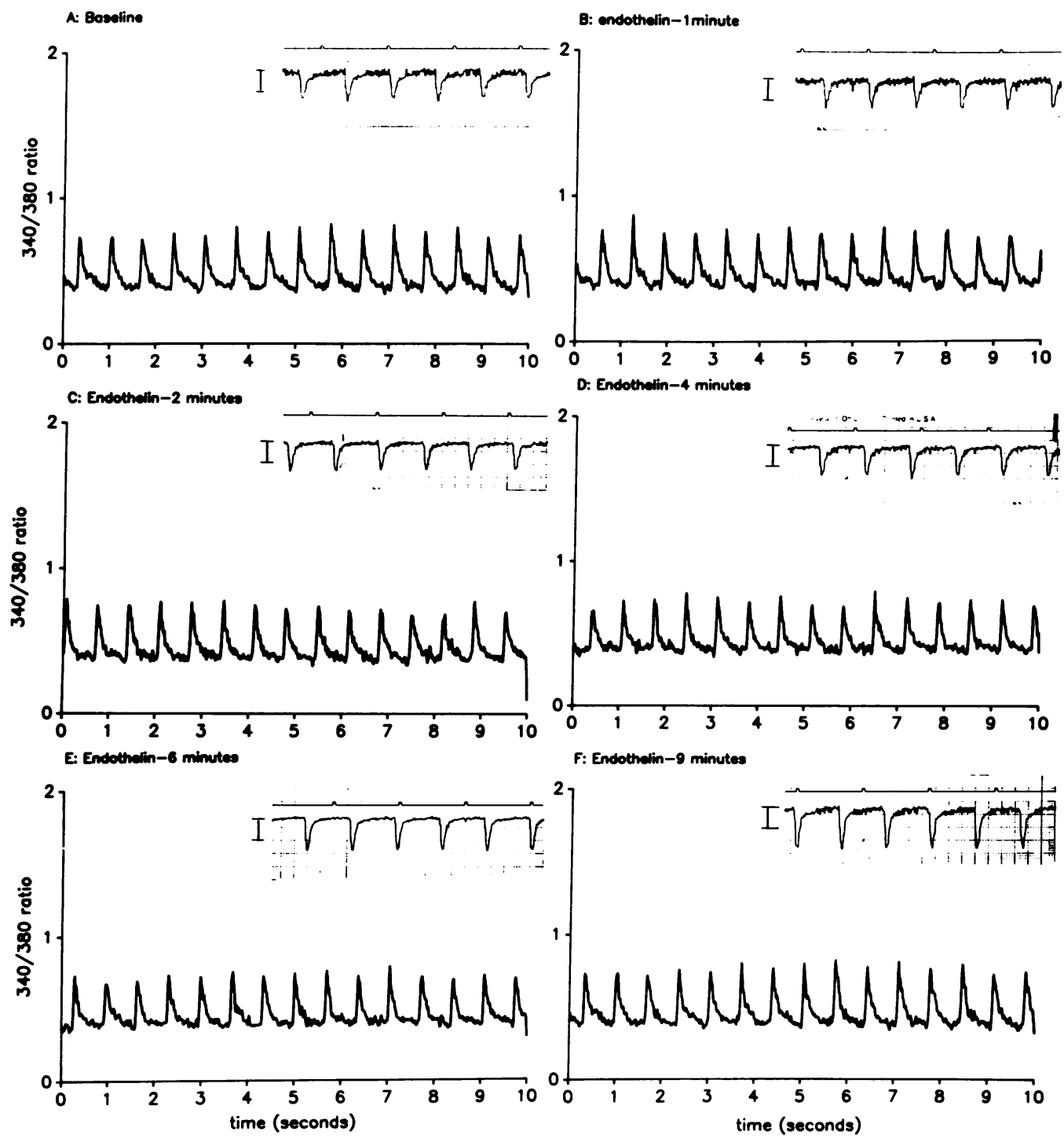

Figure 4. Time course of changes in contractile amplitude and $\left[\mathrm{Ca}^{2+}\right]_{\mathrm{i}}$-related fura-2 transients in an isolated rat ventricular myocyte exposed to $100 \mathrm{pM}$ endothelin. After collection of baseline fura-2 emission spectra at 340:380 excitation (time resolution for ratioed data of $3 \mathrm{~ms}$ ) and contractility data at baseline $\left(\left[\mathrm{Ca}^{2+}\right]_{\mathrm{o}}=0.9\right.$ $\mathrm{mM})$ in $A, 100 \mathrm{pM}$ endothelin was added to the superfusion buffer. At 1-min intervals, the cell was exposed to UV excitation light for $60 \mathrm{~s}$ only, while contractility was measured continuously. Representative 10 -s sections of each 1-min record of the ratioed fura- 2 emission spectra are shown in each panel, while concurrent contractility data are shown in the insets of each panel. The bar beside each inset equals 1 $\mu \mathrm{m}$. In neither this myocyte nor two other similarly treated cells was any increase in $\left[\mathrm{Ca}^{2+}\right]_{i}$ detected at any time point. mechanisms: (a) enhancing myofilament sensitivity to calcium, probably by increasing the affinity of troponin $\mathrm{C}$ for $\mathrm{Ca}^{2+}$; and $(b)$ by increasing the cytosolic $\left[\mathrm{Ca}^{2+}\right]$ transient, although to a lesser extent than is observed with $\beta$-adrenergic agonists for a comparable increase in contractile force.

The positive inotropic effect of endothelin was diminished by organic inhibitors of voltage-sensitive, L-type sarcolemmal calcium channels, including verapamil and nifedipine. As shown in Fig. 5, verapamil had the expected negative inotropic effect in control cells, with an $\mathrm{IC}_{50}$ of $\sim 0.5 \mu \mathrm{M}$. Verapamil also decreased the absolute magnitude of inotropic response to endothelin. However, it is of interest that the relative fall in contractile amplitude in cells treated with $100 \mathrm{pM}$ endothelin ( $\sim 33 \%$ at $1 \mu \mathrm{M}$ verapamil) was less than that seen in control cells ( a $60 \%$ decline at $1 \mu \mathrm{M})$. This suggests that the response to endothelin is relatively unaffected by or resistant to reduced $\mathrm{Ca}^{2+}$ conductance through sarcolemmal L-type channels, and is consistent with the hypothesis that endothelin may be increasing contractile amplitude by a novel mechanism, perhaps by increasing contractile element sensitivity to intracellular calcium. It is also possible that endothelin indirectly affected verapamil's binding to or action at sarcolemmal L-channels by use-dependent blockade, perhaps due to membrane hyperpolarization, although this seems less likely.

Pertussis toxin and the inotropic response to endothelin. As GTP binding proteins have been shown to be important intermediates in the transduction of many signals at the cell membrane, including those that initiate phosphatidylinositol hydrolysis and $\mathrm{Ca}^{2+}$ mobilization, we tested whether pertussis toxin-sensitive $G$ proteins might be involved in the sequence of events after endothelin-receptor binding (37). The relatively prolonged time to onset of the positive inotropic effect of endothelin was also of interest in view of recent evidence from several laboratories that endothelin rapidly induces phosphatidylinositol hydrolysis or activation of phospholipase $A_{2}$ in a number of tissues, including rat atrium $(13,39-41 \mathrm{a})$. Therefore, we also determined whether early pharmacologic effects of the peptide, possibly mediated by pertussis toxin-sensitive $G$ proteins, could be unmasked during the 4- to 5-min lag phase preceding the positive inotropic effect of the peptide.

Preincubation of freshly dissociated intact rat ventricular myocytes with pertussis toxin resulted in nearly complete abolition of subsequent pertussis toxin-induced [ $\left.{ }^{32} \mathrm{P}\right] \mathrm{ADP}$ ribosylation in membranes derived from these pretreated cells 


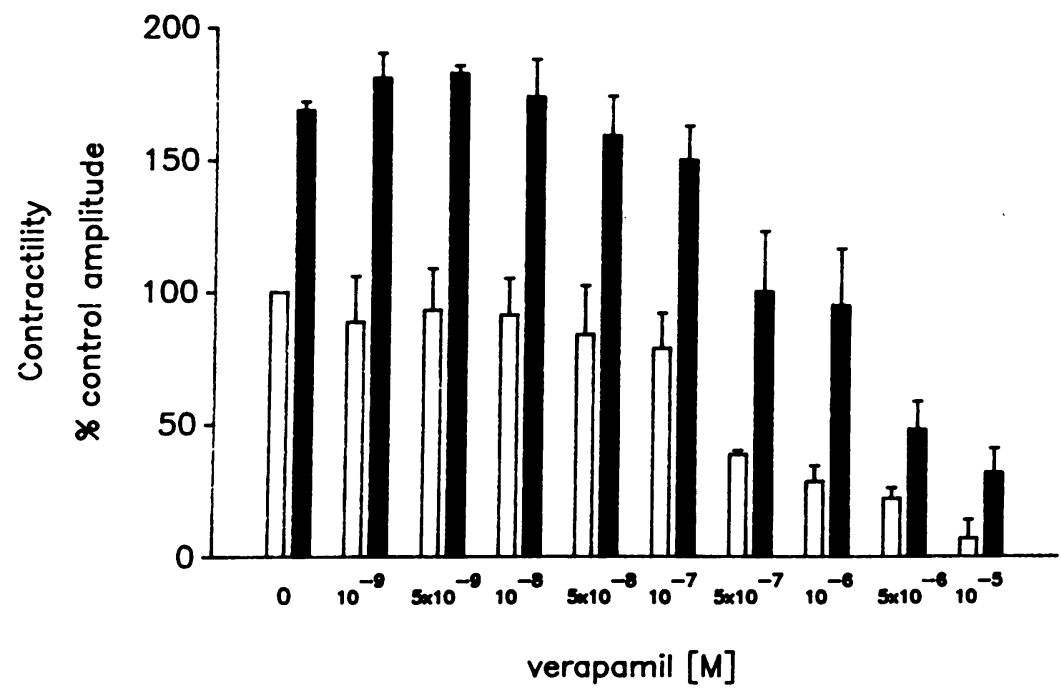

Figure 5. Verapamil and the contractile response to endothelin. Isolated rat ventricular myocytes were treated with either $100 \mathrm{pM}$ endothelin (solid bars; $n$ $=3$ ) or superfusion buffer alone (open bars; $n=3$ ) for $10 \mathrm{~min}$ at $37^{\circ} \mathrm{C}$. The increase in contractile amplitude in the three endothelin-treated cells was $169 \pm 3.2 \%$ (mean $\pm \mathrm{SD}$ ). Each cell was subsequently exposed to increasing concentrations of verapamil, from $1 \mathrm{nM}$ to $10 \mu \mathrm{M}$, as illustrated. Verapamil decreased contractile amplitude in both control and treated cells, with an $\mathrm{IC}_{50}$ of $\sim 0.5 \mu \mathrm{M}$; however, the relative decline in endothelin-treated cells appears to be less than in control cells.
(Fig. 6), as judged by the reduced intensity of 41 and $39 \mathrm{kD}$ phosphopeptide bands in treated cells consistent with the known molecular masses of the $G_{i} \alpha$ and $G_{o} \alpha$ subunits (42). In contrast to results seen with $100 \mathrm{pM}$ endothelin in nonpertussis toxin-treated cells, the peptide's positive inotropic effect was either abolished or markedly reduced $(108.1 \pm 13.4 \%$ of control amplitude, $n=9$ ) at $8 \mathrm{~min}$, the usual length of time to peak effect (Fig. 7). In addition, 6 of 9 pertussis toxin-treated cells exhibited a transient negative inotropic response at 1-2 min after exposure to endothelin $(-26.2 \pm 6.0 \%)$, and in three pertussis intoxicated cells, the contractile amplitude dropped below baseline within $1 \mathrm{~min}$ of exposure and remained there for the duration of the protocol. Pertussis toxin pretreatment alone did not alter the normal morphology of the cells, nor did it alter their response to electrical stimulation, even after $10-15 \mathrm{~min}$ of pacing at $1.5 \mathrm{~Hz}$. Because rapid effects of the $\beta$ protomers of pertussis toxin have been described in several cell types, unrelated to ADP-ribosylation of $\mathrm{G}_{\mathrm{i}} \alpha$ or $\mathrm{G}_{\mathrm{o}} \alpha$, cells pretreated with $100 \mathrm{ng} / \mathrm{ml}$ pertussis toxin for $1 \mathrm{~min}$ only were examined as a control (43). There was no evidence for any

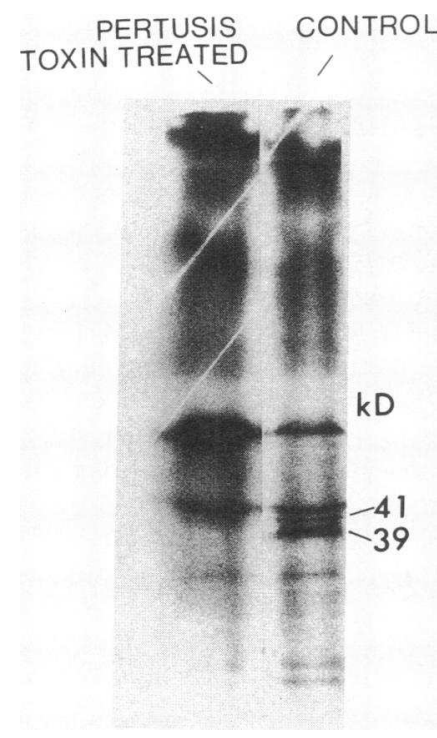

non-G protein-related rapid effects of pertussis toxin in the response of rat cardiac myocytes to endothelin.

As an additional control, isolated ventricular myocytes were incubated in the presence or absence of $100 \mathrm{ng} / \mathrm{ml}$ pertussis toxin for $3 \mathrm{~h}$ at $37^{\circ} \mathrm{C}$ in Hepes-buffered medium, and then exposed to $10 \mathrm{nM}$ isoproterenol. Pertussis toxin pretreatment increased the rise in contractile amplitude with isoproterenol to $400 \%$ of control $(n=2)$ compared to $150 \%$ of control $(n=2)$ in nonpertussis toxin-pretreated cells, as expected in response to a $\beta$ agonist after pertussis toxin. Also, although the time course of the rise in contractile amplitude was delayed, pertussis toxin had no effect on the maximal increase in contractile amplitude to either $10 \mu \mathrm{M}$ phenylephrine or 100 $\mathrm{nM}$ angiotensin in similarly treated isolated myocytes.

The unmasking of an early negative inotropic effect of endothelin in many cells by pertussis toxin, with the subsequent abolition or marked diminution of the positive inotropic action of the peptide, suggests a complex signal transduction mechanism. The negative inotropic effect could be mediated by protein kinase $\mathrm{C}$, since we have observed a decrease in contractility in response to phorbol ester exposure in primary cultures of embryonic chick cardiocytes (44). An additional, surprising observation was the effect of prior exposure of rat ventricular myocytes to isoproterenol on their subsequent contractile responsiveness to endothelin. Exposure of myocytes to low concentrations (10-100 nM) of isoproterenol for $30-40 \mathrm{~s}$ resulted in a mean 2.6-fold increase in contractile amplitude, followed by a return to baseline contractility after a 5-min washout. After this brief isoproterenol exposure, the

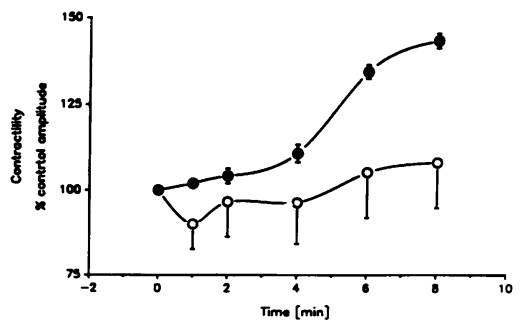

Figure 7. Pertussis toxin abolishes the contractile response to endothelin. Isolated rat ventricular myocytes were exposed to $100 \mathrm{pM}$ endothelin either after a 3-h preincubation in $100 \mathrm{ng} / \mathrm{ml}$ pertussis toxin (open circles; $n=9$ ) or prein-

cubation at $37^{\circ} \mathrm{C}$ in control media (solid circles; $n=5$ ), and the change in contractile amplitude was recorded. 
contractile response to $100 \mathrm{pM}$ endothelin was completely abolished in six of seven cells. In four of these seven cells, contractility initially declined upon exposure to endothelin, returning to baseline or slightly above only after $10 \mathrm{~min}$ of exposure to the peptide. This indicates that $\beta$ agonists can modify cellular responsiveness to endothelin's action, perhaps by partially uncoupling the activated receptor from a signal transducing $G$ protein. $\beta$ agonists could also affect another step or steps downstream in the signal transduction cascade, as they are known to desensitize myofilament responsiveness to cytosolic $\mathrm{Ca}^{2+}$, due at least in part to phosphorylation of troponin I in response to increased cAMP levels. This explanation is the more intriguing possibility given our data supporting endothelin's action enhancing myofilament sensitivity to calcium.

These observations indicate that endothelin is among the most potent inotropic substances for mammalian myocardium yet described, with a mechanism of action qualitatively different from many other endogenous agents and drugs that increase cardiac contractility. The $\mathrm{EC}_{50}$ of endothelin in isolated ventricular myocytes is at or below $50 \mathrm{pM}$, in accord with binding affinities for the cardiac sarcolemmal endothelin receptor determined in either intact tissue or sarcolemmal membranes (16-21). The onset of endothelin's action is slow while its duration is prolonged, indicating that the peptide, if it acts as an endogenous regulator of myocardial contractility in vivo, may modulate the inotropic responsiveness of the myocardium over a timeframe of minutes to hours, possibly by sensitizing the myofilaments to changes in cytosolic calcium induced by the more rapid, but shorter-lived effects of neurohumoral factors. Although an increase in cytosolic calcium in single isolated ventricular cells has been documented at endothelin concentrations of $20 \mathrm{nM}$ (45), we did not observe any consistent increase in systolic or diastolic calcium at concentrations below $1 \mathrm{nM}$.

An alternative explanation for our failure to witness an increase in intracellular $\mathrm{Ca}^{2+}$, aside from the lower concentration of endothelin used here, is our choice of species. The increase in cytosolic $\mathrm{Ca}^{2+}$ noted in rabbit myocytes (45) was accompanied by an increase in action potential duration to $470 \mathrm{~ms}$. The rat action potential is, by contrast, much abbreviated. Although we did not measure action potential duration, other qualitative differences in the force-frequency relationship between the rat and other mammalian species point to important differences in intracellular $\mathrm{Ca}^{2+}$ homeostasis (46) that could explain the absence of a rise in cytosolic $\mathrm{Ca}^{2+}$ with endothelin in the rat but not in the rabbit and, perhaps, other species. Regardless, at the stimulation frequency used here, 1.5 $\mathrm{Hz}$, the absence of any detectable rise in cytosolic $\mathrm{Ca}^{2+}$ implies that some sensitization of the contractile apparatus to $\mathrm{Ca}^{2+}$ occurred, an effect that might be apparent, to a greater or lesser degree, in other species.

Our findings suggest that the microvascular and/or endocardial endothelium of the heart, if it is the relevant source of the peptide in myocardium, and is analogous to the role described for endothelium in conduit and resistance vessels, may play a role in the modulation of cardiac contractile state, perhaps in response to changes in microvascular blood flow. Also, recent reports that the endocardial endothelium appears to modulate the inotropic response to changes in $\left[\mathrm{Ca}^{2+}\right]_{0}$ in papillary muscle $(47,48)$ are consistent with our observations that an endothelium-derived factor increases the contractile re- sponsiveness to calcium. Irrespective of the mechanism, endothelin may be one of a number of endogenous autacoids released by microvascular or endocardial endothelium, and transported vectorially to subjacent cardiac myocytes, that can act to regulate cardiac function.

\section{Acknowledgments}

We thank James D. Marsh, Thomas Michel, and Eva Neer for helpful discussions in the preparation of this manuscript, and Steven Borzak for assistance in the in situ calibration of fura-2 in adult ventricular myocytes.

This work was supported by grants HL-19259 and HL-36141 from the National Institutes of Health; by a Canadian Heart Association Research Fellowship award to H. Eid; by a grant from the Paul-Martini-Stiftung, Bonn, FRG to B. K. Krämer; and by a Clinician-Scientist Award from the American Heart Association and Faculty Development Award from the Pharmaceutical Manufacturers Association to R. A. Kelly.

\section{References}

1. Moncada, S., R. Gryglewski, S. Bunting, and J. R. Vane. 1976. An enzyme isolated from arteries transforms prostaglandin endoperoxidase to an unstable substance that inhibits platelet aggregation. Nature (Lond.). 263:663-665.

2. Furchgott, R. F., and J. V. Zawadzki. 1980. The obligatory role of endothelial cells in the relaxation of arterial smooth muscle by acetylcholine. Nature (Lond.). 288:373-376.

3. De Mey, J. G., and P. M. Vanhoutte. 1983. Anoxia and endothelium-dependent reactivity of the canine femoral artery. J. Physiol. (Lond.). 335:65-74.

4. Yanagisawa, M., H. Kurihara, S. Kimura, Y. Tomobe, M. Kobayashi, Y. Mitsui, Y. Yazaki, K. Goto, and T. Masaki. 1988. A novel potent vasoconstrictor peptide produced by vascular endothelial cells. Nature (Lond.). 332:411-415.

5. Ishikawa, T., M. Yanagisawa, S. Kimura, K. Goto, and T. Masaki. 1988. Positive inotropic action of novel vasoconstrictor peptide endothelin on guinea pig atria. Am. J. Physiol. 255:H970-H973.

6. Fukuda, Y., Y. Hirata, H. Yoshimi, T. Kojima, Y. Kobayashi, M. Yanagisawa, and T. Masaki. 1988. Endothelin is a potent secretagogue for atrial natriuretic peptide in cultured rat atrial myocytes. Biochem. Biophys. Res. Commun. 155:167-172.

7. Ishikawa, T., M. Yanagisawa, M. Kimura, K. Goto, and T. Masaki. 1988. Positive chronotropic effects of endothelin, a novel endothelium-derived vasoconstrictor peptide. Pfluegers Arch. Eur. J. Physiol. 413:108-110.

8. Hu, J. R., U. G. Berninger, and R. E. Lang. 1988. Endothelin stimulates atrial natriuretic peptide (ANP) release from rat atria. Eur. J. Pharmacol. 158:177-178.

9. Watanabe, T., K. Kusumoto, T. Kitayoshi, and N. Shimamoto. 1989. Positive inotropic and vasoconstrictive effects of endothelin-1 in in vivo and in vitro experiments: characteristics and the role of L-type calcium channels. J. Cardiovasc. Pharmacol. 13:S108-S111.

10. Moravec, C. S., E. E. Reynolds, R. W. Stewart, and M. Bond. 1989. Endothelin is a positive inotropic agent in human and rat heart in vitro. Biochem. Biophys. Res. Commun. 159:14-18.

11. Lew, R. A., and A. J. Baertschi. 1989. Endothelial cells stimulate ANF secretion from atrial monocytes in co-culture. Biochem. Biophys. Res. Commun. 163:701-709.

12. Stasch, J.-P., C. Hirth-Dietrich, S. Kazda, and D. Neuser. 1989. Endothelin stimulates release of atrial natriuretic peptides in vitro and in vivo. Life Sci. 45:869-875.

13. Vigne, P., M. Lazdunski, and C. Frelin. 1989. The inotropic effect of endothelin-1 on rat atria involves hydrolysis of phosphatidylinositol. FEBS (Fed. Eur. Biochem. Soc.) Lett. 249:143-146. 
14. Kitayoshi, T., Watanabe, and N. Shimamoto. 1989. Cardiovascular effects of endothelin in dogs: positive inotropic action in vivo. Eur. J. Pharmacol. 166:519-522.

15. Shah, A. M., M. J. Lewis, and A. H. Henderson. 1989. Inotropic effects of endothelin in ferret ventricular myocardium. Eur. J. Pharmacol. 163:365-367.

16. Power, R. F., J. Wharton, Y. Zhao, S. R. Bloom, and J. M. Polak. 1989. Autoradiographic localization of endothelin-1 binding sites in the cardiovascular and respiratory systems. J. Cardiovasc. Pharmacol. 13:S50-S56.

17. Miyazaki, H., M. Kondoh, H. Watanabe, T. Hayashi, K. Murakami, M. Takahashi, M. Yanagisawa, S. Kimura, K. Goto, and T. Masaki. 1989. Identification of the endothelin-1 receptor in the chick heart. J. Cardiovasc. Pharmacol. 13:S155-S156.

18. Hirata, Y., Y. Fukuda, H. Yoshimi, T. Emori, M. Shichiri, and F. Marumo. 1989. Specific receptors for endothelin in cultured rat cardiocytes. Biochem. Biophys. Res. Commun. 160:1438-1444.

19. Gu, X.-H., D. J. Casley, and W. G. Nayler. 1989. Characterization of [ $\left.{ }^{125} I\right]$ endothelin-1 binding sites in rat cardiac membrane fragments. J. Cardiovasc. Pharmacol. 13:S171-S173.

20. Galron, R., Y. Kloog, A. Bdolah, and M. Sokolovsky. 1989 Functional endothelin/sarafotoxin receptors in rat heart myocytes: structure-activity relationships and receptor subtypes. Biochem. Biophys. Res. Commun. 163:936-943.

21. Watanabe, H., H. Miyazaki, M. Kondoh, Y. Masuda, S. Kimura, M. Yanagisawa, T. Masaki, and K. Murakami. 1989. Two distinct types of endothelin receptors are present on chick cardiac membranes. Biochem. Biophys. Res. Commun. 161:1252-1259.

22. Inoue, A., M. Yanagisawa, S. Kimura, Y. Kasuya, T. Miyauchi, K. Goto, and T. Masaki. 1989. The human endothelin family: three structurally and pharmacologically distinct isopeptides predicted by three separate genes. Proc. Natl. Acad. Sci. USA. 86:2863-2867.

23. Haworth, R. A., D. R. Hunter, and H. A. Berkoff. 1980. The isolation of $\mathrm{Ca}^{2+}$-resistant myocytes from the adult rat. J. Mol. Cell. Cardiol. 12:715-722.

24. Cheung, J. Y., J. M. Constantine, and J. V. Vonventre. 1987. Cytosolic free calcium concentration and glucose transport in isolated cardiac myocytes. Am. J. Physiol. 252:C163-C172.

25. Borzak, S., R. A. Kelly, B. K. Kramer, Y. Matoba, J. D. Marsh, and M. Reers. 1990. In situ calibration of fura- 2 and BCECF fluorescence in adult rat ventricular myocytes. Am. J. Physiol. In press.

26. Grynkiewicz, G., M. Poenie, and R. Y. Tsien. 1985. A new generation of $\mathrm{Ca}^{2+}$ indicators with greatly improved fluorescence properties. J. Biol. Chem. 260:3440-3450.

27. Liang, B. T., E. J. Neer, and J. B. Galper. 1986. The non-coordinate development of muscarinic cholinergic inhibition and adrenergic stimulation of adenylate cyclase in embryonic chick heart. J. Biol. Chem. 261:9011-9021.

28. Laemmli, U. K. 1970. Cleavage of structural proteins during the assembly of the head of bacteriophage T4. Nature (Lond.). 227:680-685.

29. Marban, E., and T. W. Smith. 1986. Digitalis. In The Heart and Cardiovascular System. H. A. Fozzard, E. Haber, R. B. Jennings, A. M. Katz, and H. E. Morgan, editors. Raven Press, New York. 1573-1596.

30. Blinks, J. R., and M. Endoh. 1986. Modification of myofibrillar responsiveness to $\mathrm{Ca}^{2+}$ as an inotropic mechanism. Circulation. 73:85-98.

31. Lee, J. A., and D. G. Allen. 1989. Comparison of the effects of inotropic interventions on isometric tension and shortening in isolated ferret ventricular muscle. Cardiovasc. Res. 23:748-755.
32. Endoh, M., and J. R. Blinks. 1988. Actions of sympathomimetic amines on the $\mathrm{Ca}^{2+}$ transients and contractions of rabbit myocardium: reciprocal changes in myofibrillar responsiveness to $\mathrm{Ca}^{2+}$ mediated through $\alpha$ - and $\beta$-adrenoceptors. Circ. Res. 62:247-265.

33. Kent, R. L., D. L. Mann, Y. Urabe, R. Hisano, K. W. Hewett, M. Loughnane, and G. Cooper IV. 1989. Contractile function of isolated feline cardiocytes in response to viscous loading. Am. J. Physiol. 257:H1717-H1727.

34. Morgan, J. P., and J. R. Blinks. 1982. Intracellular $\mathrm{Ca}^{++}$transients in the cat papillary muscle. Can. J. Physiol. Pharmacol. 60:524528.

35. McClellan, G. B., and S. Winegrad. 1978. The regulation of the calcium sensitivity of the contractile system in mammalian cardiac muscle. J. Gen. Physiol. 72:737-764.

36. Winegrad, S., G. McClellan, A. Weisberg, L. E. Lin, S. Weindling, and R. Horowits. 1987. $\beta$-adrenergic regulation of cardiac myosin. Can. J. Physiol. Pharmacol. 65:606-609.

37. Neer, E. J., and D. E. Clapham. 1988. Roles of G protein subunits in transmembrane signalling. Nature (Lond.). 333:129-134.

38. Marsden, P. A., N. R. Danthuluri, B. M. Brenner, B. J. Ballermann, and T. A. Brock. 1989. Endothelin action on vascular smooth muscle involves inositol trisphosphate and calcium mobilization. Biochem. Biophys. Res. Commun. 158:86-93.

39. Simonson, M. S., S. Wann, P. Mene, G. R. Dubyak, M. Kester, Y. Nakazato, J. R. Sedor, and M. J. Dunn. 1989. Endothelin stimulates phospholipase $\mathrm{C}, \mathrm{Na}^{+} / \mathrm{H}^{+}$exchange, c-fos expression, and mitogenesis in rat mesangial cells. J. Clin. Invest. 83:708-712.

40. Resink, T. J., T. Scott-Burden, and F. R. Buhler. 1989. Activation of phospholipase $A_{2}$ by endothelin in cultured vascular smooth muscle cells. Biochem. Biophys. Res. Commun. 158:279-286.

41. Takuwa, N., Y. Takuwa, M. Yanagisawa, K. Yamashita, and T. Masaki. 1989. A novel vasoactive peptide endothelin stimulates mitogenesis through inositol lipid turnover in Swiss 3 T3 fibroblasts. $J$. Biol. Chem. 264:7856-7861.

41a. Griendling, K. K., T. Tsuda, and R. W. Alexander. 1989. Endothelin stimulates diacylglycerol accumulation and activates protein kinase $\mathrm{C}$ in cultured vascular smooth muscle cells. J. Biol. Chem. 264:8237-8240.

42. Jones, D. T., and R. R. Reid. 1987. Molecular cloning of five GTP-binding protein cDNA species from rat olfactory neuroepithelium. J. Biol. Chem. 262:14241-14249.

43. Banga, H. S., R. K. Walker, L. K. Winberry, and S. E. Rittenhouse. 1987. Pertussis toxin can activate human platelets. Comparative effects of halotoxin and its ADP-ribosylating S. subunit. J. Biol. Chem. 262:14871-14874.

44. Leatherman, G. F., D. Kim, and T. W. Smith. 1987. Effect of phorbol esters on contractile state and calcium flux in cultured chick heart cells. Am. J. Physiol. 253:H205-H209.

45. Lauer, M. R., M. D. Gunn, and W. Clusin. 1989. Effect of endothelin on cytosolic calcium and membrane current in single ventricular myocytes. Circulation. 80:II-194.

46. Shattock, M. J., and D. M. Bers. 1989. Rat vs. rabbit ventricle: $\mathrm{Ca}$ flux and intracellular $\mathrm{Na}$ assessed by ion-selective microelectrodes. Am. J. Physiol. 256:C813-C822.

47. Brutsaert, D. L., A. L. Meulemans, K. R. Sipido, and S. U. Sys. 1988. Effects of damaging the endocardial surface on the mechanical performance of isolated cardiac muscle. Circ. Res. 62:358-366.

48. Shah, A. M., A. L. Meulemans, and D. L. Brutsaert. 1989. Myocardial inotropic responses to aggregating platelets and modulation by the endocardium. Circulation. 79:1315-1323. 